\title{
PERIPHERAL TROUBLE: THE
SINO-INDIAN STANDOFF
Andrew Chubb
}

$\mathrm{T}$ HE FIRST HALF OF 2017 was, for the most part, relatively quiet on China's disputed periphery. But the simultaneous mid-year standoffs that broke out on land and sea showed up some of the foreign policy implications of the transition to a New Era heralded by General Secretary Xi Jinping at the Nineteenth Party Congress: from 'standing up' to 'prospering' to 'strengthening'从站起来、富起来到强 起来. ${ }^{1}$

In a sense, Xi's declaration was a case of rhetoric catching up with reality: Beijing's more muscular policy on maritime and territorial disputes began at least a decade ago. ${ }^{2}$ Indeed, Xi did not actually say when the New Era began; but, as in previous years, China's behaviour on its periphery demonstrated a firm - though not always well-grounded - expectation that prosperity should bring with it international political clout. ${ }^{3}$

In the South China Sea, the PRC successfully pressured Vietnam to suspend drilling in a promising gas prospect within the Nine-Dash Line that depicts the PRC's ambiguous claim there. Rumours swirled that Beijing had threatened to stage an attack on a Vietnamese outpost in the Spratly Islands. But military threats were probably not even necessary, as both Vietnam's economy and its offshore energy partners have become highly dependent on China. On its maritime frontier, China's era of prosperity has already become an era of strength. But high in the Himalayas, the new-era narrative bumped up against some timeless realities of geography and perception. 


\section{Roads and Ridges}

On 16 June, a Bhutanese patrol noticed a People's Liberation Army (PLA) construction team working on a road in territory claimed by both Bhutan and China. Authorities in the capital Thimphu promptly notified their security guarantors in New Delhi, and two days later Indian troops and bulldozers rolled across the border and pitched camp, blocking the Chinese road. The ensuing seventy-three-day standoff was the most serious confrontation between China and India for thirty years
— perhaps since the 1962 war, and certainly since India joined the nuclear club.

Ironically, what may have been China and India's most dangerous border crisis in recent times took place on territory not even claimed by both countries. Known as the Dolam Plateau, it forms part of the Doklam region, a longer stretch of BhutaneseChinese disputed terrain extending about forty kilometres northward.

To understand China's behaviour in the crisis, it is useful to separate it into two parts: the initial road-building

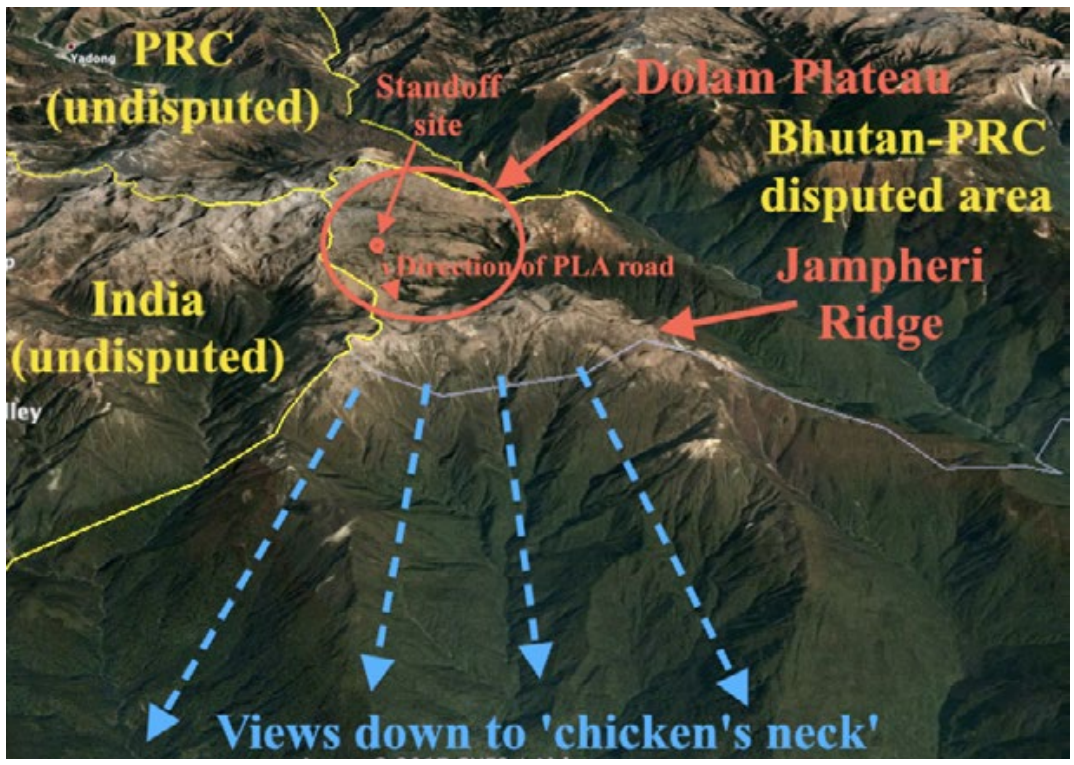

Site of the standoff: Dolam Plateau and the Jampheri Ridge Source: Google Earth 
project, and the prolonged campaign to force India to back down.

The initial incident quite possibly involved a local misunderstanding, born of poor communications and the region's unique and complex geography, rather than central policy or military strategy. ${ }^{4}$ The road the PLA sought to build would have headed in the direction of the Jampheri (Zompelri) Ridge, a line of cliffs with sweeping views right down to the narrow lowland plain that connects India's north-eastern provinces to the rest of the country. The fear that a road to the ridge might one day allow China to sever this topographical 'chicken's neck' explains India's bold intervention.

The Chinese side claimed the road-building project was an innocuous improvement of an existing track, aimed at compensating for years of upgrades to India's infrastructure on the other side of the border. Beijing said its personnel had even notified their counterparts in India of the planned works twice in the month leading up to the incident - a claim at least partially corroborated by Indian sources. ${ }^{5}$ Controlling the Jampheri Ridge might not have been the PLA's immediate intention, but India was not keen on waiting to find out.
While the initial incident may have resulted from a misunderstanding, the subsequent standoff reflected overconfidence on the part of a prosperous Party-state entering a self-designated 'New Era' of strength. Beijing's vigorous but unrealistic efforts to force New Delhi to back down resulted in a stalemate that eventually saw China pausing its road building and India withdrawing its troops and equipment.

\section{Public Pressure}

Ten days after the initial incident, China publicly accused India of 'an incursion across the China-India border ${ }^{6}{ }^{6}$ Three days after that, at a news conference, the Ministry of Foreign Affairs (MFA) handed out photographs showing Indian bulldozers and troops moving down the slope towards the PLA troops. This propelled the issue onto high rotation on state television, signalling to PRC citizens that the issue was an approved matter of public indignation.

Over the next two months, the MFA issued at least twenty more official comments on Doklam. On 2 August, it released a fifteen-page position paper narrating the events in detail, dismissing India's 'so-called security 


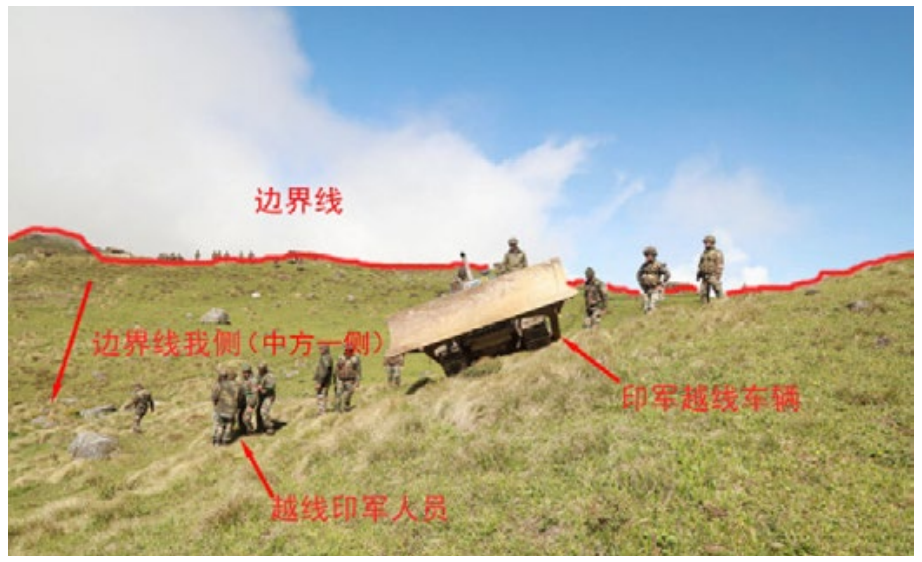

Indian troops in disputed territory. Photo released by the MFA on 29 June, 2017

Source: fmprc.gov.cn

concerns' in the area, and repeatedly demanding its immediate withdrawal from Doklam. India's Ministry of External Affairs, by comparison, issued only one public statement, responding to Beijing's accusations in a measured tone, and calling for 'utmost restraint'.

The PRC's English-language external propaganda invoked the nationalist rage of the Chinese people in commentaries aimed at sharpening India's perception of the risks of serious escalation. 'The public's patience is running short with India's Doklam transgression', opened a 24 July Global Times op-ed. 'The Chinese government will not breach the fundamental will of the people and the PLA will not let the Chinese people down', vowed one of the paper's three editorials on the topic that week. 'India should abandon the fantasy of a long-term standoff at Doklam.8

All this suggested a belief in China that India could be forced to back down in the face of a show of strength. According to Indian news reports, this was conveyed at the scene by loudspeakers blasting out warnings that India should learn the lessons of the 1962 border war, when the PLA routed its underprepared army. ${ }^{9}$ Military spokesmen in Beijing amplified the message in press briefings.

Eventually, however, the PRC had to settle for a face-saving mutual climb-down on 28 August. State media loudly hailed India's withdraw- 
al, while avoiding mention of the halted road. 'Indian side withdraws all encroaching personnel and equipment: MFA says Chinese personnel have carried out on-scene verification', crowed the China Central Television news. 'Defense Ministry says Chinese military on guard, resolutely defending sovereignty. ${ }^{, 10}$

\section{Era of Exaggeration?}

This unsuccessful attempt at coercion in the mountains suggests PRC leaders may be overestimating China's ability to get its own way on the international stage in its New Era. This could be so for at least three reasons.

First, policymakers in Beijing, far away from the scene, probably failed to appreciate their Indian counterparts' determination to keep the PLA off the Jampheri Ridge. The Foreign Ministry's peremptory dismissal of India's 'so-called security concerns' suggests this was the case.

Second, China acted as though wholly unaware of India's perspec- tive on the incident. India needed no 'reminding' of the lessons of 1962: this history was precisely the lens through which it was already viewing the events. Bitter memories of humiliation at the hands of Mao's China only bolstered India's motivation to demonstrate its resolve and regain face. ${ }^{11}$

Third, India, as a strategic competitor in the world economy, is decidedly less susceptible to the kinds of economic pressure the PRC has brought to bear on other adversaries around its periphery in recent years, such as Vietnam. India is one of the few countries in the region that has sought to counter the Belt and Road Initiative rather than welcome it. It is also seeking to deepen its ties with key PRC adversaries such as the US and Japan - and to help Vietnam and others further reduce their economic dependency on China.

In Chairman Xi's New Era, a share in China's prosperity has great allure. But, as in the past, the urge for self-preservation is often even stronger. 
This text is taken from China Story Yearbook 2017: Prosperity, edited by Jane Golley and Linda Jaivin, published 2018 by ANU Press, The Australian National University, Canberra, Australia.

doi.org/10.22459/CSY.04.2018.03A 